\section{HSE confident it can cope}

ThE UK Health and Safety Executive (HSE) is confident that it is adequately staffed to inspect all UK laboratories doing genetic engineering experiments.

In reply to questions by the House of Commons Select Committee on Science and Technology last week, the HSE said that its three specialist inspectors for microbiological research could cope with inspecting the UK's seven Category Three and two Category Four laboratories. The time lag between notification of a laboratory's intent to conduct Category Three or Four experiments and inspection had never exceeded six weeks.

Laboratories conducting Category One and Two experiments do not need to be inspected before work can commence. The HSE felt that because the inspection of these laboratories does not require such specialist knowledge, regional inspectors of medical laboratorics could cope with them. So far, about 200 experiments in 50 centres have been notified to the Genetic Manipulation Advisory Group (GMAG). Since last July the HSE and GMAG have jointly inspected 14 of the centres.

GMAG has recently had a change of membership. Seven new members, J. Chamberlain, Sir Frederick Dainton, J. Ingle, M. Kogan, C. M. Puxon, P. M. B. Walker and P. Wildy together with a new chairman Sir William Henderson started work in January. Under its new chairmanship, GMAG may be taking a more positive attitude to work with recombinant DNA. Sir William has few fears about the potential scale-up of the processes in industry. He told the select committee at a previous meeting that "the hazards of scale-up are very much less than has been anticipated". He believes that 4,500 litres of reagent in clean, sealed stainless steel flasks are probably safer than the intermediate stage: "the danger is when you move from the bench to the 5 or 10 litre scale, when you don't have adequate procedures."

GMAG is setting up a subcommittee on scale-up, and Sir William is playing close attention to its membership. He feels it should have a strong representation of chemical engineers who have experience of risk assessment in industry.

Dr Ken Duncan of the HSE shares Sir William's lack of fear about the dangers of scale-up to industrial processes when this happens, he says, the HSE will be able to call on its chemical engineers, currently engaged in other activities within the HSE, for advice. Duncan, however, does not foresee unusual problems with scale-up.

\title{
UK tightens up on lab safety
}

MANY of the recommendations of the Shooter report, which called for tighter laboratory safety regulations following the smallpox outbreak at Birmingham University, are now to be implemented by the Government. The move follows the unofficial "leaking" of the report by Clive Jenkins, general secretary of the Association of Scientific, Technical and Managerial Staffs. The Government's decision reveals that it no longer considers the country's voluntary safeguards for handling viruses in laboratories as adequate.

Social Services Secretary David Ennals told the House of Commons last week that several changes were to be made. These include:

- Regulations compelling laboratories to give notice of their proposed work. - An official licensing system to replace the present voluntary method of approving category A pathogen laboratories.

- Accepting the recommendation that category A laboratories should be inspected annually.

- Setting-up a review of the Dangerous Pathogens Advisory Group, the body responsible for approving these laboratories, to find ways of broadening its membership to include wider union and public interest.

No new legislation will be introduced to carry out these measures, which will be implemented as part of the Health and Safety at Work Act. $\mathrm{Mr}$ Ennals said public fears following the smallpox outbreak that killed medical photographer Janet Parker last September should not be allowed to cause panic. If overprotective measures were introduced, there could be great damage to the ability to carry out effective diagnosis or research.

$\mathrm{Mr}$ Ennals also revealed that a reinspection of existing category $\mathrm{A}$ pathogen laboratories-which handle smallpox, rabies, lassa fever and other dangerous viruses -is now being carried out by the Health and Safety Executive. "In some cases it has become clear that improvements in safety procedures are necessary and immediate action has been taken", he said.

Details of these cases of "immediate action" were revealed by the HSE last week and consisted of stopping work with category A pathogens at two laboratories. The first, the public health laboratory at Colindale, North London, the only centre for rabies diagnosis in Britain, was visited on January 18 by HSE inspectors and a request for an end to dangerous virus work was issued.

The order was made in the form of a Crown notice, which is not legally enforceable as one Government body cannot prosecute another, although the HSE has recently called Mr Ennals to remove Crown immunity for such laboratories. However, the director of Colindale, Dr Eric Mitchell, said a new purpose-built virus laboratoriy was to be opened there in a few weeks-after it had been inspected by the HSE, DPAG and the Home Office.

The other laboratory, at the Lister Institution in Elstree, Hertfordshire, has been asked to improve safety precautions in the production of rabies vaccines. The laboratory was closed by the institution last June, and the HSE has instructed that it must not re-open without its approval.

Robin McKie

\section{Switzerland to consider revised guidelines}

Two months ago Mrs Shirley Williams, Secretary of State for Education and Science speaking on the television programmc Weekend World, said that she would like to see the establishment of some form of international guidelines to regulate research on recombinant DNA. Commenting on the different guidelines already in operation in the United States, Britain and the European Community, Mrs Williams singled out Switzerland as one country operating outside these formal rules. There was a need, she said, to induce it to come within some form of "containment barrier".

Switzerland is of course the home of the large multinational pharmaceutical companies F. Hoffmann-La Roche, Sandoz and Ciba-Geigy. Roche and Ciba are both aware of the com- mercial possibilities of genetic engineering - and both have a finger in the pie. Roche sponsors the Basle Institute for Immunology and Ciba the Friedrich Miescher Institute, also in Basle. Both institutes have begun recombinant DNA research which is, as yet of a fundamental, rather than an applied nature.

But all recombinant DNA research in Switzerland whether commercially, privately or publicly sponsored is subject to certain controls. The controlling agency is a commission set up by the Swiss Academy of Medical Sciences in 1975. In an open letter dated April 1978, the commission set out its control policy. It was the commission's view that the U.S. National Institutes of Health (NIH) guidelines should operate in Switzerland and it recom- 